\title{
Insecticidal activity of citric acid and its soluble powder formulations against Aphis craccivora under laboratory conditions.
}

\author{
Ashraf M. Abd El-Baset El-kady; Azza I. Mohamed and Aziza H. Mohamady. \\ Central Agric. Pesticide Laboratory, Agricultural Research Center, Dokki, Egypt.
}

\begin{abstract}
Anionic surfactant sodium dodecyl sulphat (SDS) was used as wetting agent to prepare citric acid as soluble powder formulation. The prepared formulation showed stability and passed successfully all physico-chemical properties for soluble powder formulations. The insecticidal activity of active ingredient and its formulations were compared with citric acid (SP 90\%) that prepared by El-kady (2008) through using non-ionic surfactant against different stages of Aphis craccivora under laboratory conditions.

The results showed that, the active ingredient showed a slight activity against Aphis craccivora after two hours from treatment and increased gradually to give the high effectiveness after 12 hours. On the other hand all formulations were more effective against nymphs than adults and winged. With the other point of view the prepared $\mathrm{Sp}$ formulations were more effective than their active ingredient. The increasing in this effectiveness of test formulations depended on type of wetting agents, exposure periods and treated stage.
\end{abstract}

\section{INTRODUCTION}

The cowpea aphid, Aphis craccivora (Koch) is a serious pest of leguminous crop production (El-Ghareeb et al., 2002), this is by different ways include: nutrient drain which cause direct reduction of plant productivity, transmission of viruses, phytotoxicity as a result of saliva toxins of certain aphid species and excretion of honey dues which attract saprophytic fungi, which cover the leaf surface and accelerate the ageing of leaves (Schepers, 1988). Many growers, aware of the legume aphid's role in disease transmission, spray insecticides even where aphid densities are relatively low (Johnson et al., 1989). Research on alternative nature measures to chemical control has increased because aphicidal treatments have become unreliable and expensive (Hardes and Ainsworth, 1993).

The successful use of any active ingredient depends on its correct formulation into a preparation which can be applied for crop protection with safety to those applying materials to animal life and to the environment. In general, formulation plays an important role in spread over a very large area. Also, it facilitates penetration of the active ingredient to reach its target and achieve its action.

Soluble powder formulations "SP" are the simplest formulation, the pesticide which can be formulated, is limited by solubility and hydrolytic properties (FAO, WHO Meeting, 2002).

The purpose of this work is to formulate of an organic acid (citric acid) as SP formulation and testing the efficiency of those formulations against cowpea aphid.

MATERIAL AND METHODS

A) Tested chemical:

a- Citric acid (2- hydroxy propane 1,2,3tricarboxylic acid, molecular weight $(192.193 \mathrm{mg} / \mathrm{mol})$ that were supplied by El-Gomhoria Co., Cairo, Egypt.

b- Citric acid (SP 90\%) that used tween 20 as wetting agent according to El-kady (2008).

c- Surface active agent, Anionic surfactant sodium dodecyl sulphate (SDS).

B) Physico-chemical characteristics of the basic formulation:

a- Surfactants:

1-Hydrophilic - lipophilic balance (HLB):-

The solubility of surfactant in water is 
considered as approximate guide to its hydrophilic-lipophilie balance (HLP) (Lynch and Griffin, 1974).

2- Cirtical micelle concentration (CMC). $\mathrm{CMC}$ is the concentration at which the surface tension of the solution does not decrease with further increase in surface concentrations. CMC of tested surfactant was determined according to Osipow (1964).

3- Surface tension: It was measured by Du-Nouy tensiometer for solutions containing $0.5 \%(\mathrm{~W} / \mathrm{V})$ active ingredient.

4- Free acidity or alkalinity: It was according to the method of WHO specification (1979).

b- Active ingredient:

1- Free acidity or alkalinity: It was determined according to WHO specification (1979) as mentioned before.

2- Solubility: It was determined by measuring the volume of distilled water, acetone and xylene for complete solubility or miscibility of one gram of active ingredient at $20{ }^{\circ} \mathrm{C}$ (Nelson and Fiero, 1954). The solubility was calculated according to equation: $\%$ solubility $=\mathrm{w} / \mathrm{v} \mathrm{x}$ 100 (where; w: active ingredient weight, $\mathrm{V}$ : volume of solvent required for complete solubility).

C) Preparation of soluble powder formulations:

This type of formulation is suitable for compounds which are soluble in water.

This formulation was prepared by mixing surfactant with active ingredient in three forms $(95 \%+5 \%),(92.5+7.5 \%)$ and $(90 \%+10 \%)$ respectively.

D) Physico-chemical properties for the prepared soluble powder formulations:

The following physico- chemical properties were determined for the above three mixtures of the prepared formulation before and after heat storage $\left(54 \pm 2^{\circ} \mathrm{C}\right)$ for three days.

1- Surface tension: the SP's should have low surface tension when diluted with water for achieving wettability and spreading on treated surface which is irreversibly correlated to surface tension value. The surface tension was determined as mentioned before.

2- Solubility: It was determined as mentioned before.
3- Free acidity or alkalinity: It was determined as mentioned before.

E) Bioassay: The slide- dip technique assay as described by Harlow and Lampert (1990) was used to evaluate the insecticidal activity of active ingredient (citric acid) and their formulations against bean aphid stages.

All stages were transferred by a fine paint brush. Insects were first gently touched with the brush to withdraw their proboscis from leaves, than were transferred and affixed to double faced scotch tape tuck tightly to slide on their dorsal part of the body. The slides were then dipped into active ingredient solution and their formulation for 10 seconds and excess solution of alternative or their formulations were taken off with filter paper. Three slides (30 aphids) were used for each of the concentrations.

Mortality percentage was recorded 2, 4, 6 and 12 hours after treatment based on the lack of antennae and leg movement upon probing with a fine artist's paint brush.

\section{F) Statistical analysis:}

Correction of mortality, $\mathrm{LC}_{50}$, confidence intervals, and slops were determined using software package "LD-P line", copyright of Dr. Ihab. M. Baker, Plant Protection Research Institute, Egypt. Increasing in effectiveness of active ingredient as resulting to formulation was determined using El-kady formula (2008):

$\mathrm{EC}_{50}$ of active ingredient $-\mathrm{EC}_{50}$ of formulation / $\mathrm{EC}_{50}$ of active ingredient

RESULTS AND DISCUSSION

A) Evaluation of insecticidal effect of citric acid as active ingredients against different stages of Aphis craccivora:

As found in table (1) citric acid showed effectiveness against all tested stages of $A$. craccivora. Under all exposure periods this effectiveness was noticed as no or slight effect after 2 hours and increased gradually to give highly effectiveness after $12 \mathrm{hrs}$. Depending on $\mathrm{LC}_{50}$ values, the tested compounds were more effective against nymphs, followed by adult and then winged stages at all exposure periods. $\mathrm{LC}_{50}$ and slope values of tested compound changed from exposure 
period to other, also from tested stage to other.

Table (1) Insecticidal effect of citric acid as active ingredient against different stags of Aphis craccivora under lab conditions

\begin{tabular}{|c|c|c|c|c|c|c|c|c|}
\hline \multirow{3}{*}{ Stages } & \multicolumn{8}{|c|}{ Exposure periods } \\
\hline & \multicolumn{2}{|c|}{$2 \mathrm{hr}$} & \multicolumn{2}{|c|}{$4 \mathrm{hr}$} & \multicolumn{2}{|r|}{$6 \mathrm{hr}$} & \multicolumn{2}{|c|}{$12 \mathrm{hr}$} \\
\hline & 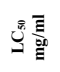 & $\frac{\frac{o}{5}}{\omega n}$ & 焉暨 & $\frac{\frac{\partial}{5}}{\frac{\pi}{n}}$ & 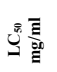 & $\frac{\frac{o}{2}}{\frac{5}{n}}$ & 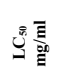 & $\frac{\frac{o}{5}}{\frac{\pi}{n}}$ \\
\hline Nymph & 2.5 & $0.85 \pm 0.42$ & 1.2 & 1.38 & CM & -- & CM & - \\
\hline Adult & 22.1 & 1.04 & 7.7 & $1.01 \pm 0.35$ & 3.4 & $1.4+0.35$ & 2.5 & $1 \pm 0.43$ \\
\hline Winged & $\mathrm{NE}$ & -- & $\mathrm{NE}$ & -- & 44.1 & $0.85 \pm 0.56$ & 18.7 & $0.71 \pm 0.46$ \\
\hline
\end{tabular}

B) Preparation of citric acid as soluble powder formulations.

1- Physico-chemical properties of active ingredient and the tested surfactants.

Table (2) showed that the active ingredient of citric acid was insoluble in xylene where showed highly solubility in water $(100 \%)$ and low solubility in acetone (11.1\%). According to FAO, WHO Meeting (2002) on pesticides specification, the pesticide which can be formulated is limited by solubility and hydrolytic, therefore, solubility powder formulation is suitable form for the tested material.

Table (2) Physico- chemical properties of active ingredient
of citric acid.
\begin{tabular}{|c|c|c|c|c|}
\hline \multirow{2}{*}{ Materials } & Solubility at $25^{\circ} \mathrm{C}(\mathrm{wt} / \mathrm{v})$ in & $\begin{array}{c}\% \text { free } \\
\text { acidity as } \\
\mathrm{H}_{2} \mathrm{So}_{4}\end{array}$ \\
\cline { 2 - 5 } & Water & Acetone & Xylen & 45.6 \\
\hline $\begin{array}{c}\text { Citric } \\
\text { acid }\end{array}$ & 100 & $11-1$ & Insoluble & \\
\hline
\end{tabular}

Also, the active ingredient of citric acid compound was acidic. The \% free acidity was 45.6 .

2) Physico-chemical properties of surface active agent.

As shown in table (3) anionic surfactants SDS was soluble in water and not soluble in acetone and xylene, also it have HLB value $>13$ so, it could be considered as detergent because they are complete soluble in water where as here CMC value was $0.3 \%$ and possess a low surface tension 30.3 dyne $/ \mathrm{Cm}$ for above results be concluded that, the SDS is suitable as wetting agent to prepare the soluble powder formulations.

Table (3): The physico-chemical properties of the tested surface active agents.

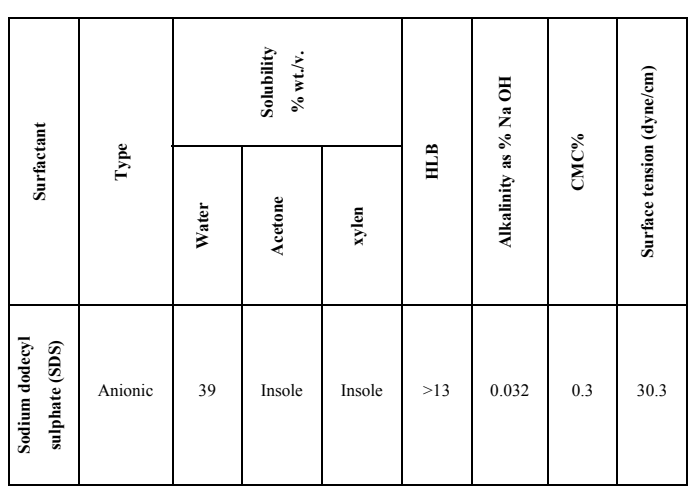

Surfactants applied to soluble powder will reduce the surface tension of spray droplets that spread over treated surface providing more coverage for toxicant by decreasing contact angle of spray on solid surface (El-Sisi, 1985).

3) Physico-chemical properties of spray solution for the locally prepared sp formulation.

In table (4) the mixture of active ingredient (citric acid) and SDS gave low surface tension when diluted at $0.5 \%$ in water.

Table (4) preparation and physico-chemical properties of soluble powder formulations

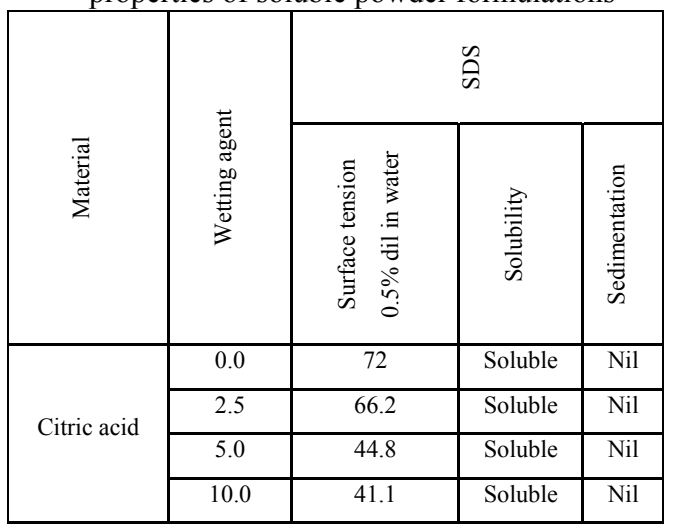

Also surface tension, decreased by increasing the concentration of surfactant. Many researchers have observed the lack of correlation between surface tension and wetting characteristics of formulations and their performance (Parr and Norman, 1965, Hull et al., 1982 and Sand and Bachelard, 1973). The mixture of active 
ingredient and SDS should be used since it improved spreading wet ability and retention of sprayed solution. Bioactivity increases while surface tension of sprayed solution decreased (Osipow, 1964). Also all prepared $\mathrm{sp}$ formulation is completely soluble in water without any sedimentation, and this $\mathrm{sp}$ gave clear solution when added to water.

According to data presented in table (5), no changes were found in solubility, sedimentation and free acidity of the prepared SP formulation before and after heat storage. According to Anonyomous (1973), no any precipitation or flocculating should be occurred when SP diluted with water at field application rate.

Table (5) Effect of heat storage on physico-chemical properties of locally SP formulation

\begin{tabular}{|c|c|c|c|c|c|c|}
\hline \multirow[b]{2}{*}{ 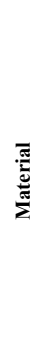 } & \multicolumn{3}{|c|}{ Before storage } & \multicolumn{3}{|c|}{ Heat storage } \\
\hline & 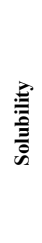 & 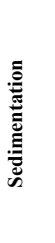 & 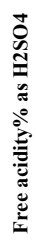 & 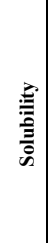 & 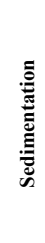 & 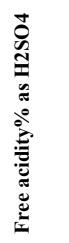 \\
\hline 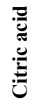 & 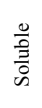 & $\bar{z}$ & $\underset{\infty}{\overbrace{\infty}}$ & 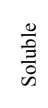 & $\overline{\bar{z}}$ & $\underset{\infty}{\infty}$ \\
\hline
\end{tabular}

According to data presented in table (6), generally the effectiveness of citric acid as SP formulations increased against all tested stages of $A$. craccivora compared with effectiveness of active ingredient alone.

This indication may be due to the role wetting agents that reduced the surface tension of spray droplet that spread on the body surface in insect stage providing more coverage for toxicant by decreasing contact angle of spray drops on body surface, with other view wetting agent may be facilitate the penetration of active ingredient to reach its target and achieve its action. On the other hand, the effectiveness of the tested formulations depended on the type of wetting agent
(Anionic or nonionic), treated stage and exposure periods as follow:-

\section{1) Type of wetting agent:}

Depending on $\mathrm{LC}_{50}$ values citric acid was more effective against nymph when SDS was as wetting agent in their formulations than tween 20 after 2 and 4 hours, also the same indication was noticed in case of winged after 4,6 and 12 hours.

\section{Table (6) Evaluation of citric acid as SP formulations against stages of Aphis craccivora under lab conditions.}

\begin{tabular}{|c|c|c|c|c|c|c|c|c|c|}
\hline \multirow{3}{*}{ 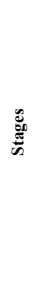 } & \multirow{3}{*}{ 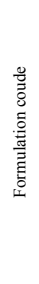 } & \multicolumn{8}{|c|}{ 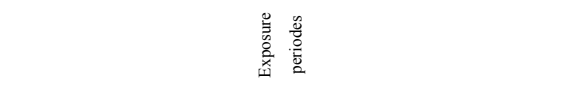 } \\
\hline & & \multicolumn{2}{|c|}{ 는 } & \multicolumn{2}{|c|}{$\frac{气}{y}$} & \multicolumn{2}{|c|}{ 홍 } & \multicolumn{2}{|c|}{ 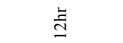 } \\
\hline & & $\begin{array}{l}\text { 员㫛 } \\
\text { 照 }\end{array}$ & $\frac{\circ}{\frac{0}{6}}$ & 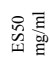 & $\frac{\circ}{\frac{0}{\sigma}}$ & 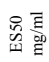 & $\frac{0}{\frac{\partial}{\omega}}$ & 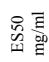 & $\frac{\check{5}}{\omega}$ \\
\hline \multirow{2}{*}{ 言 } & $\mathrm{C}_{\mathrm{l}}$ & 0.158 & $\begin{array}{c}1.04 \\
\pm \\
0.31\end{array}$ & 0.029 & $\begin{array}{c}0.72 \\
\pm \\
0.82\end{array}$ & CM & -- & $\mathrm{CM}$ & - \\
\hline & $\mathrm{C}_{2}$ & 0.682 & $\begin{array}{c}1 \\
\pm \\
0.32\end{array}$ & 0.166 & $\begin{array}{c}0.93 \\
\pm \\
0.30\end{array}$ & CM & -- & CM & -- \\
\hline \multirow{2}{*}{ 言 } & $\mathrm{C}_{\mathrm{l}}$ & 30.7 & $\begin{array}{c}0.75 \\
\pm \\
0.62\end{array}$ & 4.7 & $\begin{array}{c}0.71 \\
\pm \\
0.47\end{array}$ & 0.395 & $\begin{array}{c}1.02 \\
\pm \\
0.31\end{array}$ & 0.121 & $\begin{array}{c}1.24 \\
\pm \\
00.33\end{array}$ \\
\hline & $\mathrm{C}_{2}$ & $\mathrm{NE}$ & -- & 0.121 & $\begin{array}{c}0.66 \\
\pm \\
0.5\end{array}$ & 0.284 & $\begin{array}{c}2.15 \\
\pm \\
0.5\end{array}$ & 0.008 & $\begin{array}{c}0.65 \\
\pm \\
0.5\end{array}$ \\
\hline \multirow{2}{*}{$\begin{array}{l}\bar{\Xi} \\
\text { 品 } \\
\text { 咅 }\end{array}$} & $\mathrm{C}_{\mathrm{l}}$ & $\mathrm{NE}$ & -- & 6.5 & $\begin{array}{c}0.83 \\
\pm \\
0.38\end{array}$ & 0.118 & $\begin{array}{c}0.92 \\
\pm \\
0.44\end{array}$ & 0.131 & $\begin{array}{c}0.80 \\
\pm \\
0.31\end{array}$ \\
\hline & $\mathrm{C}_{2}$ & $\mathrm{NE}$ & -- & $\mathrm{NE}$ & -- & 6.5 & $\begin{array}{c}0.72 \\
\pm \\
0.36\end{array}$ & 0.215 & $\begin{array}{c}0.50 \\
\pm \\
0.29\end{array}$ \\
\hline
\end{tabular}

$\mathrm{C} 1=\mathrm{C}+\mathrm{SDS} \mathrm{C} 1=\mathrm{Citric}$ acid + SDS

$\mathrm{C} 2=\mathrm{C}+\mathrm{T} \quad \mathrm{C} 2=\mathrm{Citric}$ acid + Tween

$\mathrm{NE}=$ Not Effect $\quad \mathrm{CM}=$ Complete Mortality

On contrast citric acid was more effective against adult when tween 20 was as wetting agent in their formulation after 4, 6 and 12 hours. This indication may be due to nature of wetting agent influencing on pesticidal activity. The ability of a surfactant to reduce surface tension depends on the hydrophilic-hydrophobic relationships and the propensity of molecules to arrange them selves as the interfaces of different phases (i.e. between the droplet and air and or between the droplet and treated surface) (Mukerjee and Mysels, 1971). 


\section{b) Testes stages:}

The effectiveness of tested formulations changed from stage to another. Generally tested formulations of active ingredient was more effective against nymph followed by adult and then winged, this indication may be due to sensitivity of each stage that depended on morphological and physiological factors of each stage.

\section{c) Exposure periods:}

Generally, the effectiveness of tested to formulations increased by increasing the exposure periods, this indication may be due to the mode of action of this compounds. These results agree with data obtained by El- kady 2008.

The increasing in effectiveness of active ingredient as resulting to formulation was tabulated in table (7) the obtained data indicated that formulation increased the effectiveness of citric acid to reach $100 \%$ mortality after 4 hours in case of nymph with two tested formulation $\mathrm{C}_{1}$ and $\mathrm{C}_{2}$. On the other hand, the increasing in effectiveness of active ingredient was 95.2 and 99.7 in case of $C_{1}$ and $C_{2}$ formulation against adult where as it was 99.3 and 98.9 in case of $C_{1}$ and $C_{2}$ formulations against winged.

Table (7) Increase in effectiveness of citric acid as resulting to formulation after $12 \mathrm{hrs}$ from treatment.

\begin{tabular}{|c|c|c|}
\hline Stages & Formulation Code & \% of Increasing effectiveness at 12hr \\
\hline \multirow{2}{*}{ Nymph } & $\mathrm{C}_{1}$ & CM No change \\
\cline { 2 - 3 } & $\mathrm{C}_{2}$ & CM No change \\
\hline \multirow{2}{*}{ Adult } & $\mathrm{C}_{1}$ & 95.2 \\
\cline { 2 - 3 } & $\mathrm{C}_{2}$ & 99.7 \\
\hline \multirow{2}{*}{ winged } & $\mathrm{C}_{1}$ & 99.3 \\
\cline { 2 - 3 } & $\mathrm{C}_{2}$ & 98.9 \\
\hline
\end{tabular}

\section{REFERENCES}

Anonymous (1973). Specification for Pesticides Used in Public Health, Geneva,WHO.

Bayer and Lumb, J.M. (1973): Penetration and translocation of herbicides in w. van valkenburg.(Ed). Pesticide formulations. Marcel- Dekker, inc., New York, pp:387-439.

El-Ghareeb, M. ;M.A.K. Nasser; A.M.K. El-sayed and G.A. Mohamed (2002): Possible mechanisms of insecticide resistance in cowpea aphid, Aphis craccivora (Koch)- The role of general esterase and oxidase enzymes in insecticide resistance of cowpea. The first Conf. of The Central Agri. Pesticide Lab.,3-5 Sep., Vol.(2): 635649.

El-kady, A.M.A. (2008).Formulation and Determination the Nematicidal activity of alum and citric acid against rootknot nematode, Meloidogyne incognita.J.Agric. Sci. Mansoura Uni., 33(1): 533- 539,2008

El-Sisi, A.G.(1985).Preparation of some insecticidal formulations using local constituent and testing their efficiency. Ph.D. Thesis. Fac.of Agric.Cairo Univ. Foliar pests of watermelon in Hawaii. Tropical Manag., 35: 90-96.

Food and Agricultural Organization, World Health Organization (2002). Manual on Development and Use of Pesticides, prepared by $\mathrm{FAO} / \mathrm{WHO}$ Joint Meeting on Pesticide Specifications (JMPS), $1^{\text {st }}$ Ed., Rom.

Hardee, D.D. and J.M. Ainsworth (1993).Cotton aphid (Homoptera: Aphididae): J. Econ. Entomol, 86: 2130:2135.

Hull, H. M., Davis , D.G. and Stolzenberg, G.E.(1982):In Adjuvants for herbicides, ed.R.H.Hodgson. Weed Sci. Soc.Amer., 1982,PP. 26-67. Harlow,C.D. and E.P. Lampert (1990). Resistance mechanism in two color forms of the tabacco aphid(Homoptera:Aphididae)

Johnson, M.W.; R.F.L. Mau; A. P. Marlinez and S. Fukuda (1989). Foliar pests of watermelon in Hawaii. Tropical Manage., 35:90-96. J. Econ. Entamol.86 : 2130-2135.

Lynch, M.I. and W.C. Griffin (1974).Food Emulsions. In: Emulsion Technology, by Lissant,K.J.,Marcell Decker, Inc., New York. Mukerjee, P. and K.J. Mysels (1971). Critical Micelle concent rations of queues surfactant systems National Bureau of Standards Washington DC, PP.1-21

Nelson, F.G. and G. L. Fiero (1954). A selected aromatic fraction naturally occurring in petroleum as insecticides solvents. J. Agri. Food Chem., 4: 735737. 
Osipow, L.I. (1964). Theory and industrial applications. Reinhold Publishing Crep., New York, 473 pp.

Parr,J.F. and A.G. Norman,1965, Bot.Gaz.,26-56.

Sand,R. and E.P. Bachelard (1973). New phytol., 72: 69-86.
Schepers, A. (1988): Control of aphids, chemical control, pp89-121. In Aphids: their biology, natural enemies and control; world crop pests, 2C, A.k.Minks and P. Harrewijn \{eds\}. Elsevier, Amsterdam

\section{ARABIC SUMMARY}

$$
\begin{aligned}
& \text { النشاط الإبادى لحمض الستريك و مستحضر اته علي شكل مساحيق قابلة للأوبان } \\
& \text { في الماء ضد حشرة من الفول Aphis craccivora } \\
& \text { أشرف محمود عبد الباسط القاضى ـ عزة إسماعيل محمد ـ عزيزة حسن محمدي }
\end{aligned}
$$

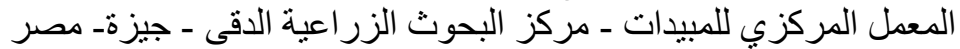

استخدمت مـادة Sodium dodecyl sulphate الانيونية كمو اد مبللة لتجهيز حمض الستريك علي

$$
\text { صورة مساحيق قابلة للذوبان فى الماء. }
$$

وقد اجتازت هذه المركبـات اختبـار ات الصفات الفيزيقيـة و الكيميائية لهذه التجهيز ات طبقا للمعايير

$$
\text { الدولية. }
$$

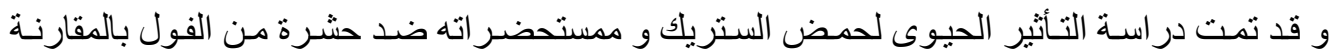

بمستحضر حمض الستريك المحضر بو اسطة القاضى 2008و الذى استخدم فى تحضيره مو اد مبللة غير أنيونية. و قد أظهرت النتائج الآتى:

أظهر حمض الستريك بمفرده تأثنير طفيف بعد سـاعتين من المعاملة وز ادت الفاعلية بعد ذلاعلك تدريجيا

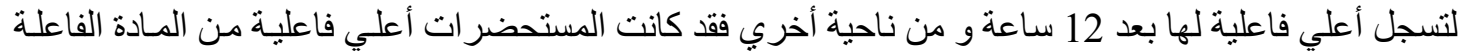

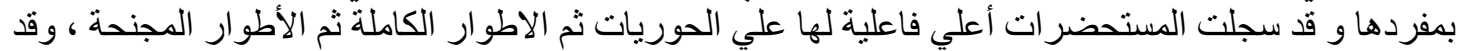
ارتبطت الزيادة فى الفاعلية بنوع المادة المبللة و فترة التعريض ولئ الطور الطبات المعامل. 